Technical Report 959

\title{
Toward a Theory of Adaptive Training
}

\author{
John A. Boldovici
}

U.S. Army Research Institute

Field Unit at Orlando, Florida

Stephen L. Goldberg, Chief

\section{Training Systems Research Division Jack H. Hiller, Director}

U.S. Army Research Institute for the Behavioral and Social Sciences 5001 Eisenhower Avenue, Alexandria, Virginia 22333-5600

Office, Deputy Chief of Staff for Personnel

Department of the Army

July 1992

Approved for public relases; distribution is unilmited. 